\title{
TRADISI DAYAK LEBO DAN BUDAYA ROCK-ART DI KALIMANTAN TIMUR
}

\author{
Bambang Sugiyanto* \\ Balai Arkeologi Banjarmasin, Jalan Gotong Royong II, RT. 03/06, Banjarbaru 70711, \\ Kalimantan Selatan; Telepon/facsimile +62 5114781716
}

\begin{abstract}
Abstrak. Di kawasan karst Sangkulirang telah ditemukan sejumlah gua yang menyimpan gambar cadas. Penemuan tersebut menunjukkan bahwa budaya gambar cadas tidak hanya berkembang di kawasan Indonesia bagian timur. Saat ini, di sekitar kawasan karst Sangkulirang berdiam masyarakat Lebo yang memiliki budaya penguburan di dalam gua. Berdasarkan data lingkungan, tradisi, dan etnohistori masyarakat Lebo, tulisan ini membahas identitas masyarakat Lebo dan hubungan tradisinya dengan budaya gambar cadas di kawasan karst Sangkulirang. Hasil kajian menunjukkan bahwa lokas hunian dan tradisi masyarakat Lebo yang masih memiliki anasir prasejarah mengarahkan dugaan adanya 'pewarisan budaya' dan proses budaya yang berlanjut di kawasan Sangkulirang.
\end{abstract}

Kata kunci: kawasan karst, gambar cadas, penguburan, upacara panen, sarang lebah

Abstract. ROCK-ARTS AND TRADITION OF THE LEBO PEOPLE IN EAST KALIMANTAN. In the karst region of Sangkulirang, a number of caves have found containing rock-arts. Such discovery suggests the rockarts are developed not only in eastern Indonesia, but in the western region as well. Today, around the karst region of Sangkulirang dwells the Lebo people who practice burials in cave crevices. Based on environmental data, tradition, and ethno-history of the Lebo people, this paper discusses the identity and relationship of the Lebo cultural tradition with the rock-arts in the karst region of Sangkulirang. The result showed that the settlement locations and tradition of the Lebo people still indicates prehistoric elements which suggests a 'cultural bequeathing' and cultural process have continued in Sangkulirang.

Keywords: karst region, rock-arts, burial, harvest ceremony, beehive

\section{A. Pendahuluan}

Sejak tahun 1994, wilayah pedalaman Kalimantan Timur, khususnya kawasan karst yang berada di wilayah administrasi Kabupaten Kutai Timur mulai ramai membahas mengenai rock-art mulai dari Situs Gua Mardua sampai ke Gua Tewet. Sebelumnya, tidak pernah terpikirkan bahwa wilayah Kalimantan akan mempunyai budaya rock-art seperti yang ditemukan di Sulawesi Selatan, Sulawesi Tenggara, Kepulauan Maluku, dan Papua. Budaya rock-art ini bahkan pernah diduga hanya berkembang di wilayah Indonesia bagian timur saja, dan untuk wilayah Indonesia bagian barat belum pernah ditemukan.

\footnotetext{
* Penulis adalah Peneliti Madya pada Balai Arkeologi Banjarmasin, email: iyan_balar_bjb@yahoo.com
} 
Pendapat itu mulai berubah sejak diketahuinya situs dengan temuan rock-art pertama di wilayah Kalimantan, oleh tim peneliti dari Perancis. Situs itu adalah Liang Kaung, yang berada di hulu Sungai Kapuas, di wilayah Kabupaten Kapuas Hulu, Provinsi Kalimantan Barat. Penemuan ini terjadi pada tahun 1992. Rock-art di Situs Liang Kaung merupakan goresan dan gambaran manusia prasejarah dengan menggunakan arang pada media dinding gua. Penemuan ini mengilhami mereka untuk lebih semangat lagi dalam mencari situs-situs rock-art lainnya. Mulai tahun 1993, mereka mengalihkan lokasi penelitian ke wilayah Kalimantan Timur dengan prioritas lokasi daerah sepanjang aliran Sungai Mahakam. Kegiatan ini tampaknya tidak menemukan sesuai dengan harapan, dan mereka beralih ke wilayah yang ada di sekitar Pegunungan Sangkulirang. Di kawasan Sangkulirang yang mempunyai sumber daya alam kawasan karst rupanya merupakan daerah keberuntungan mereka. Di sinilah mereka menemukan situs Gua Mardua, di Desa Pengadan, yang merupakan situs cap tangan pertama yang ditemukan di wilayah Kalimantan Timur.

Penemuan situs Gua Mardua ini memberikan bukti yang jelas bahwa budaya rock-art juga pernah berkembang di wilayah Kalimantan, tidak hanya di wilayah Indonesia bagian timur saja. Selanjutnya, mereka mulai mengeksplorasi kawasan karst lainnya yang ada di Sangkulirang, dan hasilnya luar biasa, mereka menemukan beberapa situs dengan temuan rock-art lain seperti Liang Kambing, Liang Saleh, dan Liang Kairim. Selanjutnya, mereka bertambah semangat dan terus mengeksplorasi hampir semua kawasan karst yang berdekatan dengan lokasi situs yang telah ditemukan. Kawasan karst yang sudah dikunjungi meliputi kawasan Sangkulirang,
Tanjung Mangkalihat, dan Merabu Mapulu (khusus ini berada di wilayah administrasi Kabupaten Berau). Situs rock-art di kawasan Tanjung Mangkalihat antara lain: Gua Tengkorak, Gua Ham, Gua Kurang Tahu, Gua Tamrin, Gua Tewet, dan Gua Tebor. Sementara situs di kawasan Merabu Mapulu adalah Gua Beloyot.

Satu hal yang menarik dari penemuan situs-situs rock-art di kawasan karst di pedalaman Kalimantan Timur adalah kenyataan bahwa lokasi situs-situs ini juga merupakan wilayah kehidupan masyarakat Dayak Lebo. Dayak Lebo ini masih mempunyai kekerabatan dengan Dayak Basap yang masih satu famili dengan Dayak Punan. Masyarakat Dayak Lebo ini menempati desa atau dusun-dusun kecil yang ada di sekitar kawasan karst Sangkulirang,Tanjung Mangkalihat, dan Merabu Mapulu (gambar 1). Satu lagi tradisi suku Lebo yang mempunyai kedekatan dengan budaya prasejarah yang pernah berkembang di sini adalah tradisi penguburan yang mereka lakukan di atas atau di dalam liang (gua) dengan menggunakan wadah kubur dari kayu yang disebut lungun. Situs kubur tradisi seperti ini antara lain; Situs Ceruk Lungun di Desa Pengadan, Gua Lungun di Pegunungan Marang (keduanya di wilayah Kabupaten Kutai Timur), dan Gua Badak di Desa Merabu Mapulu (Kabupaten Berau).

Tradisi penguburan yang masih dilakukan oleh masyarakat Dayak Lebo ini menunjukkan adanya kedekatan antara mereka dengan manusia pendukung budaya rock-art yang pernah berkembang di pedalaman Kalimantan Timur di masa lalu. Satu lagi tradisi yang bisa menunjukkan kedekatan Dayak Lebo dengan budaya prasejarah rock-art adalah tradisi upacara kehidupan yang berhubungan erat dengan 


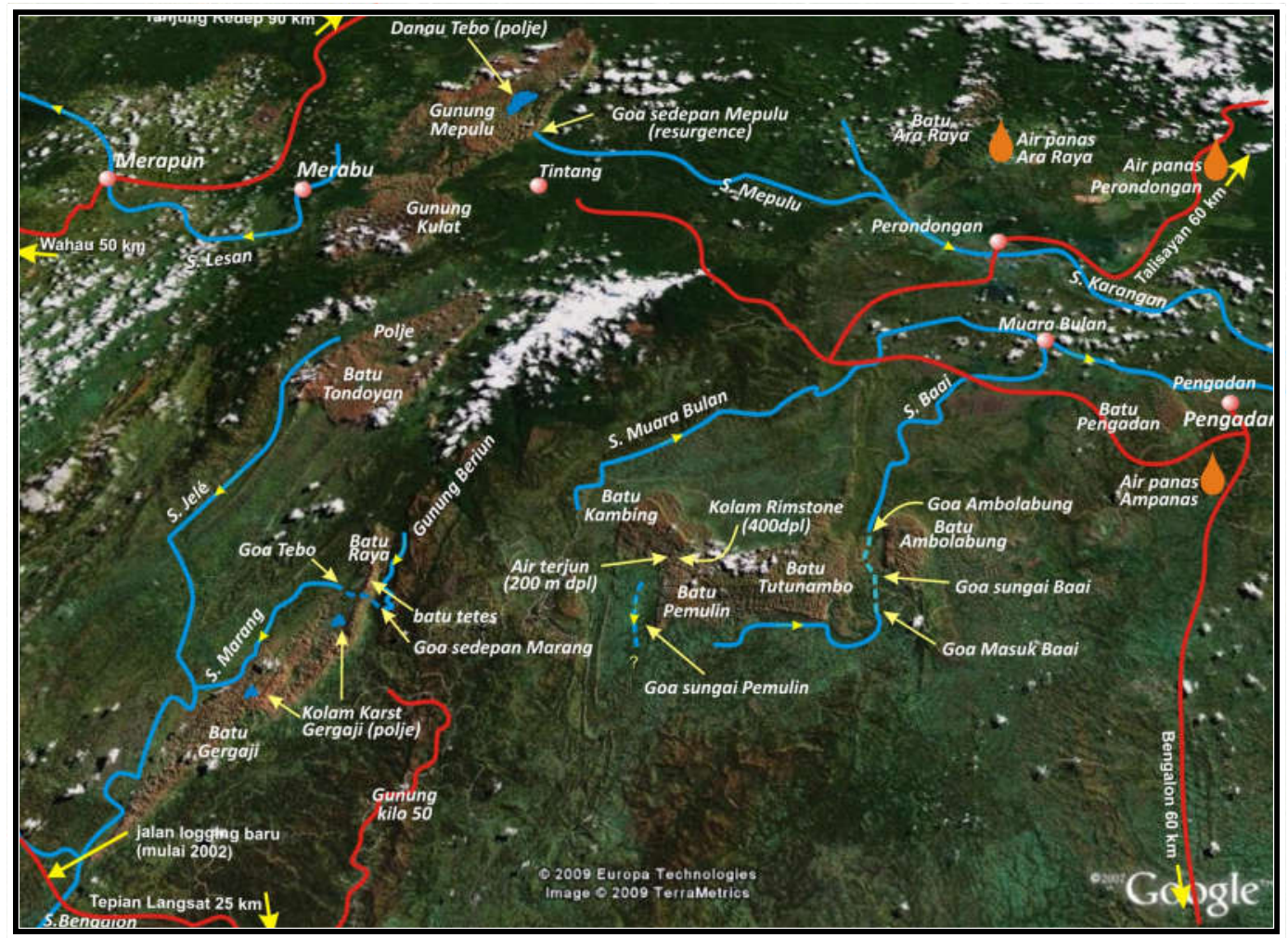

Gambar 1. Jalur transportasi yang sering digunakan oleh masyarakat Dayak Lebo melalui jalur sungai (biru) dan jalan setapak (merah) di Pegunungan Mangkalihat dan Sangkulirang (dok. Pindi Setiawan)

keberhasilan panen mereka. Upacara ini dilaksanakan sebagai ucapan syukur dan terima kasih mereka pada roh nenek moyang yang telah membantu dalam memelihara tanaman dan ternak mereka, sehingga dapat menghasilkan bahan makanan yang berlimpah. Pelaksanaan upacara ini menggunakan media kayu yang dihiasi penuh dengan corak sarang madu. Mereka percaya dan yakin jika mereka dapat melaksanakan upacara ini dengan baik, mereka akan mendapatkan hasil tanaman dan buruan yang lebih baik di waktu yang akan datang. Tradisi ini sangat erat kaitannya dengan salah satu motif rock-art berupa sarang madu yang ada di Liang Karim.

\section{B. Permasalahan}

Berdasarkan keberadaan data-data arkeologi yang ditemukan di wilayah masyarakat Dayak Lebo dan adanya tradisi yang masih dilakukan, menunjukkan ada hubungan antara keduanya. Bagaimana bentuk hubungan itu menjadi bahan penelitian yang menarik untuk dilaksanakan ke depan. Dalam makalah ini, penulis berusaha untuk mencari hubungan tersebut dengan menggunakan data tentang lingkungan, tradisi, dan sejarah Dayak Lebo, yang akan dikomparasikan dengan data budaya rock-art yang ada di Kalimantan Timur. Beberapa pertanyaan menarik yang dapat diajukan sebagai permasalahan antara lain: 
1. Siapakah masyarakat Dayak Lebo?

2. Apa saja tradisi Dayak Lebo yang mempunyai kemiripan dengan budaya prasejarah yang ada di pedalaman Kalimantan Timur?

3. Apakah tradisi tersebut merupakan hasil keberlanjutan atau pengembangan lokal?

\section{Pembahasan}

Kehadiran masyarakat Dayak Lebo di wilayah Provinsi Kalimantan Timur memang masih menimbulkan banyak pertanyaan. Secara biologis mereka kelihatan seperti kebanyakan penduduk asli Kalimantan lainnya, seperti Dayak Kenyah, Kayan, Iban, dan lain-lain. Hal yang membedakan hanyalah faktor bahasa yang mereka gunakan sehari-hari. Bahasa Lebo yang mereka gunakan sebagai bahasa pergaulan seharihari inilah yang menjadi nama etnis mereka. Dayak Lebo menurut informasi dari tetua adat memang masih mempunyai hubungan erat dengan Dayak Basap dan masih keluarga besar dari famili Dayak Punan. Secara umum Dayak Lebo antara lain tersebar di wilayah Kabupaten Berau dan Kabupaten Kutai Timur, terutama di sekitar kawasan karst di Merabu Mapulu, Sangkulirang, dan Tanjung Mangkalihat.

Menurut legenda, masyarakat Dayak Lebo berasal dari daerah di sekitar Danau Tebo (Danau Deberu), yang berada di hulu Sungai Benaan. Danau Tebo ini oleh masyarakat Dayak Lebo sering disebut dengan "Pesu Raya" (yang artinya air besar). Dikisahkan pada jaman dahulu masyarakat Dayak Lebo awalnya tinggal dan menetap di sekitar Danau Tebo ini. Mereka memilih tinggal di sini karena Danau Tebo menyediakan banyak sumber bahan makanan melimpah berupa berbagai jenis ikan dan udang yang ada di dalam danau yang tidak pernah kering, meskipun kemarau panjang. Masyarakat Dayak Lebo hidup dengan tenang, tenteram, dan damai. Berawal dari kesalahan dalam pelaksanaan erau (pesta adat), masyarakat Dayak Lebo dihukum dengan bencana banjir yang menenggelamkan seluruh rumah dan pemukiman. Jika air danau surut, konon dapat terlihat bekas-bekas rumah penduduk berupa tonggak-tonggak kayu. Salah satu bukti yang cukup bisa diajukan jika Danau Tebo merupakan lokasi awal pemukiman masyarakat Dayak Lebo adalah terdapat banyak sekali peninggalan sisa penguburan dengan menggunakan wadah lungun pada liang-liang yang banyak terdapat di sekitar Danau Tebo.

Setelah bencana itu, masyarakat Dayak Lebo mulai terpencar dalam beberapa kelompok, seperti:

1. Kelompok Merapun yang meliputi Merapun, Merabu Mapulu, Panaan (Sungai Layan),

2. Tintang (Tukat Canong), dan Peronggong.

3. Kelompok Tabalar

4. Kelompok Inaran

5. Kelompok Perondongan, yang meliputi desa Karangan, Baai, dan Muara Bulan

6. Kelompok Bengalon dan Tepian Langsat

Bagi kelompok Merapun, daerah pemukiman yang dianggap paling tua atau lama ada di Tintang. Boleh dikatakan, setelah pemukiman di sekitar Danau Tebo hilang ditelang air bah, masyarakat Dayak Lebo yang selamat mulai menata kehidupan baru di Tintang, sampai sekitar tahun 1961-an, sebagian besar mulai berpindah ke daerah baru seperti Perondongan, Merapun, Merabu, Mapulu, dan Panaan. Perpindahan ini juga didukung karena mulai terbatasnya kualitas 
sumber daya alam di Tintang, sehingga tidak lagi mencukupi keperluan hidup masyarakat Dayak Lebo. Oleh karena itu, mereka mulai bergerak secara berkelompok menuju daerah-daerah baru di atas yang lebih mudah dicapai dan menyediakan sumber bahan makanan yang lebih baik. Memang, secara morfologis, Tintang merupakan lokasi yang susah dicapai karena berada di lembah perbukitan karst yang lumayan tinggi dan curam. Bagi penduduk yang masih muda, tidak ada hambatan tetapi untuk yang sudah berumur akan menjadi satu hambatan yang cukup menyulitkan. Perpindahan penduduk ini juga tidak disertai dengan pedoman adat istiadat Dayak Lebo, sehingga di tempat yang baru hampir tidak ada lagi pelaksanaan upacara adat Dayak Lebo, seperti tenar, tiwan, dan lain-lain.

Perpindahan masyarakat dari lokasi awal sekitar Danau Tebo ke Tintang tidak jelas terjadi kapan waktunya. Keyakinan masyarakat Dayak Lebo sangat tinggi bahwa nenek moyang mereka yang tinggal di Tintang memang merupakan keturunan langsung dari merekaa yang pernah tinggal di Danau Tebo. Bahkan konon masyarakat Dayak Lebo di Danau Tebo dulunya tinggal dalam rumah besar yang disebut dengan Lebo Mengan, yang terdiri dari banyak petak untuk masingmasing keluarga. Rumah besar ini dibuat untuk mengantisipasi masalah keamanan dan ancaman perang. Selain itu, masyarakat Dayak Lebo juga mempunyai kebiasaan tinggal dalam liang-liang batu yang banyak terdapat di gunung karst di sekitar pemukiman mereka. Kebiasaan ini dilatarbelakangi oleh mata pencaharian mereka yang senang mencari sarang burung dan sarang madu, selain itu juga karena alasan sembunyi dari ancaman musuh dan menyimpan barangbarang pusaka.
Kelompok masyarakat Dayak Lebo lain yang ada di wilayah Kabupaten Berau adalah kelompok Tabalar dan kelompok Inaran, berada di sepanjang DAS Tabalar dan Inaran. Lokasi pemukiman lama mereka berpusat di Desa Tabalar dan Desa Inaran. Dari kedua pemukiman ini banyak juga anggota masyarakat Dayak Lebo yang berpindah ke Merapun, Panaan, bahkan sampai ke Perondongan di Kecamatan Karangan, Kabupaten Kutai Timur. Masyarakat Dayak Lebo memang dikenal suka berjalan menyusuri jalan-jalan setapak di antara pegunungan dan perbukitan karst untuk mencari lubang sarang burung dan binatang yang bisa dikonsumsi. Sarang burung walet yang saat ini mempunyai nilai ekonomis tinggi sudah lama dikenal oleh masyarakat dayak Lebo. Konon beberapa tahun Ialu, sarang burung itu hanya dimanfaatkan sebagai makanan ternak (anjing). Masyarakat Dayak Lebo sangat familiar dengan kondisi lingkungan pegunungan dan perbukitan karst yang ada di sekitar pemukiman mereka, sehingga mereka sangat hafal dengan letak dan posisi gua yang ada. Gua-gua yang ada ini memang tidak semuanya mereka manfaatkan, hanya sebagian kecil saja yang dimanfaatkan sebagai lokasi hunian atau penguburan. Sementara sebagaian besar gua yang ada mereka jadikan sebagai tempat penangkaran burung walet yang menghasilkan sarang yang punya nilai jual tinggi.

Masyarakat Dayak Lebo yang ada di wilayah Kabupaten Berau dan Kutai Timur, dikenal mempunyai kebiasaan untuk saling mengunjungi di antara keluarga atau kerabat. Masyarakat Dayak Lebo yang tinggal di wilayah Merapun sering berjalan pulang pergi ke perkampungan orang Lebo di desa yang lain seperti Tintang, Perondongan, dan lainnya. 
Perjalanan ini dilakukan melalui jalan setapak di antara pegunungan dan perbukitan karst serta sungai-sungai. Bahkan dikisahkan perjalanan dari Merabu ke Tintang dapat dilakukan dalam waktu 1-2 hari perjalanan. Kebiasaan berjalan jauh dan kemampuan dalam beradaptasi dengan lingkungan karst ini yang kemungkinan besar membuat masyarakat Dayak Lebo dapat berada di beberapa tempat pemukiman yang berada di sekitar pegunungan karst Sangkulirang, Tanjung Mangkalihat, dan Merapu Mapulu.

Di ketiga lokasi pegunungan karst di atas, boleh dikatakan hampir semua masyarakat Dayak Lebo menggunakan bahasa pergaulan yang sama yaitu Bahasa Lebo, yang juga dijadikan nama kelompok dayak mereka. Menurut penuturan para tetua adat Dayak Lebo, bahasa yang dulu digunakan oleh masyarakat Dayak Lebo yang lama (lebih tua), yang merupakan keturunan dari Dayak Basap, adalah Bahasa Lebo Isi. Bahasa Lebo Isi ini banyak digunakan di Inaran, KaranganPengadan, Batu tepok, Tabalar, Bengalon, dan Tepian Langsat. Sekarang, tidak banyak lagi dari anggota masyarakat Dayak Lebo yang bisa menggunakan bahasa Lebo Isi, mereka sekarang lebih mengenal Bahasa Lebo yang baru.

Berdasarkan keterangan di atas, dapat disimpulkan bahwa dalam sejarah perkembangan masyarakat Dayak Lebo, terdapat empat desa lama yang penting untuk dikaji lebih mendalam, guna mengetahui sejarah masyarakat Dayak Lebo dengan lebih baik, yaitu: Desa Tintang (tukat canong), Mapulu Lama, Peronggong, dan Panaan Lama (Sungai Layar). Kempat desa Dayak Lebo lama ini mengacu pada satu lokasi pemukiman paling awal yaitu Danau Tebo (Pesu Raya) yang berada di hulu Sungai Benaan. Setelah terjadinya kesalahan dalam pelaksanaan pesta adat (erau), yang berakibat pada tenggelamnya pemukiman di Danau Tebo, masyarakat Dayak Lebo mulai berkembang di keempat desa di atas. Dari Tintang, berkembang ke Merapun dan Merabu, sementara dari Panaan Lama tetap berkembang menjadi satu desa yang lebih besar.

Tradisi penguburan dan tradisi pengambilan sarang madu yang dilakukan Dayak Lebo tampaknya mempunyai persamaan dengan apa yang ada dalam situs prasejarah di kawasan karst Sangkulirang, Mangkalihat, dan Merabu Mapulu. Situs penguburan prasejarah antara lain ditemukan di Gua Tengkorak, Gua Kebobo, dan Liang Jon. Sisa penguburan di ketiga situs ini masih dapat dilihat sebagai jenis penguburan primer tanpa penggunaan wadah kubur. Dalam budaya penguburan prasejarah pada awalnya memang tidak dikenal penggunaan wadah kubur. Mayat biasanya langsung dikuburkan pada suatu lubang dalam tanah baik di lokasi terbuka atau tertutup seperti di dalam gua atau lubang batu. Pada perkembangan yang kemudian, jenis penguburan langsung (primer) ini mulai berkembang dengan adanya penguburan kedua (sekunder). Pada tahap penguburan ini mulai digunakan wadah kubur mulai dari bahan kayu, tembikar, atau keramik, bahkan dari bahan batuan masif. Budaya batu masif ini kemudian terkenal dengan budaya megalitik, yang banyak berkembang di kepulauan Indonesia, Sebenarnya di kawasan karst di Kecamatan Gunung Tabur, Kabupaten Berau, juga pernah ditemukan situs gua hunian dan penguburan prasejarah. Situs Gua Payau yang pernah diteliti oleh Karina Arifin dkk. dari Jurusan Arkeologi Universitas Indonesia, Jakarta, menunjukkan adanya sisa penguburan individu prasejarah. 
Situs penguburan yang bisa dikatakan mempunyai kesamaan dengan lokasi penguburan masyarakat Dayak Lebo, adalah Ceruk Lungun di desa Pengadan dan Liang Lungun di Pegunungan Marang. Kedua situs penguburan ini menggunakan wadah kubur lungun yang dilengkapi dengan pola hias yang cukup raya. Sementara itu, situs penguburan Dayak Lebo antara lain ada di Gunung Badak, Batu Maut, dan Gunung Ara Raya. Di Gunung Badak terdapat Iokasi penguburan yang cukup tinggi, Ceruk Badak. Di Batu Maut, banyak terdapat lubang-lubang batu yang digunakan untuk penguburan lungun, dan di Gunung Ara Raya, terdapat tiga buah gua yang digunakan untuk lokasi penguburan, yaitu: Gua Alan Bilan, Gua Awan Biru, dan Gua Pelangiran. Lokasi penguburan Dayak Lebo ini berdekatan dengan situs-situs rock-art dan hunian prasejarah yang ada di pedalaman Kalimantan Timur (gambar 2).

Masyarakat Dayak Lebo sekitar empat dasawarsa yang lalu, masih melakukan tradisi penguburan dengan menggunakan wadah kubur lungun seperti yang ada di Liang Badak, Liang Bertingkat, dan Liang Saban di daerah Merabu Mapulu. Lokasi penguburan itu sampai sekarang masih dipelihara oleh masyarakat Dayak Lebo yang tinggal di desa Merapun, Merabu Mapulu, dan Panaan. Sekarang dengan masuknya agama Islam, Kristen Katolik, dan Kristen Protestan,

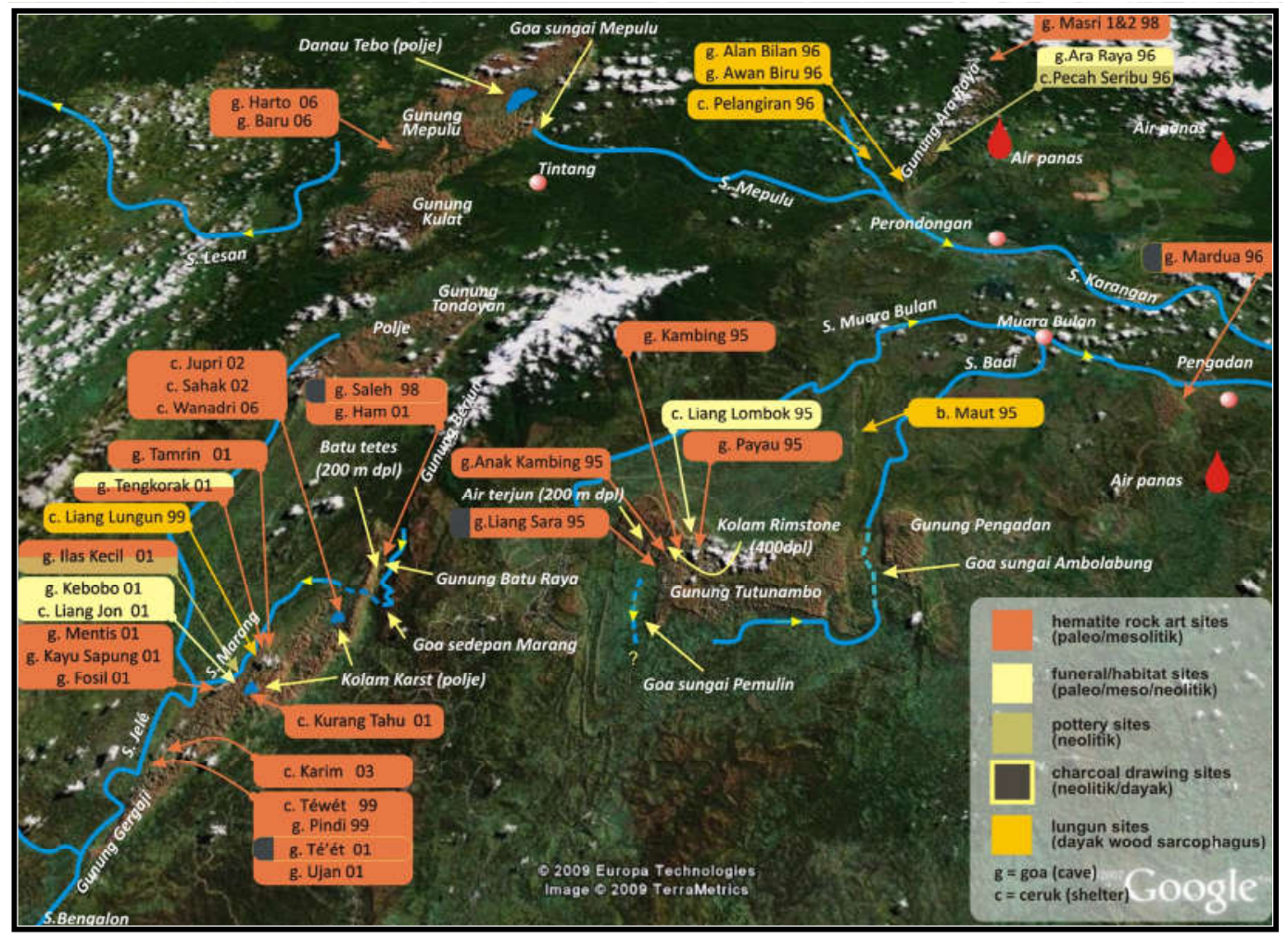

Gambar 2. Lokasi situs rock-art, situs hunian prasejarah, dan situs penguburan tradisional Dayak Lebo (dok. Pindi Setiawan). 
tampaknya tradisi penguburan ini sudah ditinggalkan dan diganti dengan penguburan dengan lubang dalam tanah.

Sementara itu, tradisi lama yang masih dilakukan sampai sekarang adalah tradisi pencarian dan pengambilan madu yang sering mereka temukan dalam hutan. Menurut penuturan Bapak Lampas (75 tahun), salah seorang anggota masyarakat Dayak Lebo yang terakhir melaksanakan upacara adat baik untuk pengobatan (ngenjong) maupun kehidupan (Erau Merabu), tradisi pencarian dan pengambilan sarang tawon (madu) ini dilakukan dalam satu kelompok dengan aturan yang sangat ketat dan mengikat. Dikisahkan oleh Bapak Lampas bahwa sarang tawon ini biasanya ditemukan di dalam hutan yang jauh dari pemukiman penduduk. Keberadaan sarang tawon ini juga tidak dapat diperkirakan, sehingga unsur kebetulan dan keberuntungan tampaknya bisa menemukan sarang tawon yang diinginkan. Aturan yang diberlakukan dalam proses pengambilan madunya adalah sebagai berikut: setelah penemuan sarang tawon yang penuh dengan madu, kemudian dibentuklah satu tim kecil yang bertugas untuk mengambil sarang dan madu yang ada didalamnya. Semua orang yang menjadi anggota tim pengambilan ini hanya bekerja pada pagi sampai sore hari, dan mereka harus selalu ikut dalam tahapan pengambilan sarang tersebut, tidak boleh ada yang absen sampai pekerjaan tersebut selesai. Pengambilan sarang atau pemotongan sarang juga dilakukan sesuai dengan aturan adat yang sudah ditetapkan dari dulu, yaitu mereka menggunakan tali untuk memanjat pohon dimana sarang tawon berada. Kemudian mereka mengusir kawanan tawon dengan seikat rumput kering yang dibakar, asap dari batang rumpur inilah yang diharapkan dapat mengusir atau mengubah orientasi si lebah (tawon). Bakaran rumput kering itu dijatuhkan ke bawah dan kawanan lebah mengikutinya sehingga sarangnya bisa diambil dengan mudah. Kemudian dengan menggunakan sebuah pisau dari kayu yang telah ditajamkan, mereke mulai memotong-motong sarang tadi dan secara perlahan memasukkan dalam ember yang terbuat dari sebuah jerigen yang sudah dimodifikasi sehingga dapat digunakan untuk menambung banyak potongan sarang lebah. Mereka yakin jika menggunakan pisau kayu, sarang lebah dan madunya akan lebih awet dan tahan lama jika dibandingkan dengan menggunakan pisau besi.

Selanjutnya dikisahkan oleh Bapak Lampas, bahwa masyarakat Dayak Lebo mempunyai satu adat istiadat yang sekarang sudah jarang dilakukan lagi, yaitu adat erau. Dalam erau ini masyarakat Dayak Lebo melakukan tradisi menari dan menyanyikan lagu-lagu adat yang hanya dilaksanakan pada malam hari. Sementara untuk pagi sampai siang mereka tetap bekerja seperti biasa. Pelaksanaan erau ini biasanya dilakukan dalam waktu 3-5 hari. Diakhir acara mereka akan mengadakan acara kebersamaan yang sangat unik, di mana semua orang yang ada di kampung itu tidak boleh marah, masyarakat mempunyai hak untuk bersuka cita yang dilaksanakan dengan saling mengotori pakaian teman, mencoreng dengan arang dan lain sebagainya. Sesudah melaksanakan erau ini, masyarakat Dayak Lebo merasa yakin jika desa yang mereka tinggali ini akan "gemah ripah loh jinawi" subur makmur dengan berbagai pohon buah dapat berproduksi dengan baik dan melimpah hasilnya. Salah satu peralatan yang harus ada dalam upacara erau adalah sepasang papan panjang yang nantinya akan digunakan sebagai tempat duduk para tamu yang akan menari selama 
berlangsungnya upacara ini. Sepasang papan ini dibuat dengan bentuk panjang, pipih, dan tidak begitu besar. Seluruh permukaan papan ini digambari bentuk sarang lebah, kambing, sapi, kerbau dan lainlain. Semua jenis binatang yang dipelihara tampaknya ada di dalam papan tersebut. Dominasi gambar sarang lebah merupakan unsur utama dalam penggambaran papan upacara erau. Hal ini merupakan bukti bahwa dalam kehidupan masyarakat Dayak Lebo, sarang lebah mempunyai fungsi yang sangat penting. Hal ini sangat erat hubungan dengan penemuan gambar-gambar sarang tawon/ lebah yang ada di dinding gua di pedalaman Kalimantan Timur. Salah satu gua yang mempunyai gambar itu adalah Liang Karim, di pegunungan Marang, Kabupaten Kutai
Timur. Gambaran tentang sarang tawon ini menunjukkan bukti pada kita semua bahwa manusia prasejarah pada masa lalu sudah mengenal dan mengerti bagaimana memanfaatkan madu dari sarang tawon yang biasanya terdapat di dalam hutan-hutan di Kalimantan.

Gambar 3 adalah sketsa ulang dari motif rock-art sarang madu yang ada di situs Liang Karim, Sangkulirang, yang dikerjakan oleh Luc-Henry Fage. Motif sarang madu ini menunjukkan bahwa pada masa lalu, manusia prasejarah pendukung budaya rockart di sini ada, terlihat bahwa keberadaan sarang madu ini pada sebuah ranting atau dahan pohon dalam jumlah yang cukup banyak. Penggambaran lukisan sarang madu ini sangat cocok dengan kondisi yang

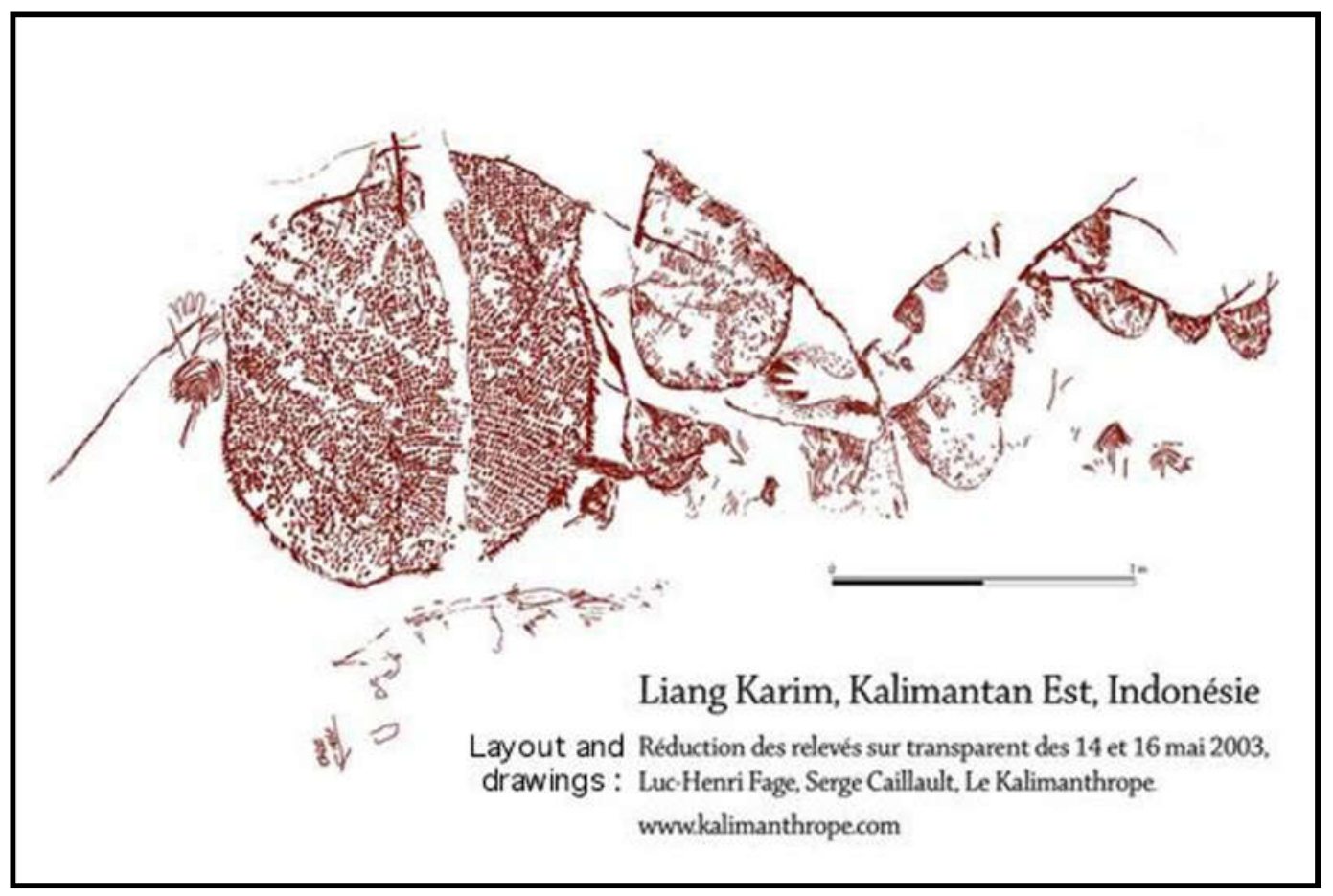

Gambar 3. Sketsa sarang lebah di Liang Karim (dok. Luc-Henri Fage et.al) 
sebenarnya, di mana masyarakat Ddayak Lebo sering menjumpai dan menemukan sarang madu yang jumlahnya lebih dari satu pada sebuah pohon. Dari kejauhan, terlihat pohon tersebut seperti gambar atau motif rock-art yang ada di Liang Karim.

\section{Kesimpulan}

Berdasarkan hasil penelitian bersama Indonesia-Perancis di pedalaman Kalimantan Timur, terungkaplah jika di wilayah tersebut ternyata mempunyai sumberdaya budaya yang sangat penting bagi perkembangan sejarah Bangsa Indonesia. Di wilayah pegunungan karst Mangkalihat dan Sangkulirang, serta Merabu Mapulu (Berau) ternyata memiliki banyak gua yang di dalamnya terdapat budaya Rock-art yang sangat spektakuler. Temuan ini mengubah cakrawala arkeologi selama ini, bahwa budaya rock-art hanya akan ditemukan di bagian timur Indonesia, mulai dari Sulawesi sampai Papua. Temuan ini bersama temuan serupa di Gua Harimau (Sumatera Selatan) telah merubah pandangan dan paradigma lama, dan membuktikan jika budaya rock-art juga pernah melintas wilayah Kalimantan dan Sumatera dengan intensitas yang berbeda. Hubungan yang erat antara masyarakat Dayak Lebo yang sekarang menghuni wilayah di sekitar lokasi gua-gua yang mempunyai budaya rock-art tampaknya dapat dianalisis dari adanya kedekatan dan kesamaan tradisi yang dapat kita amati. Kedekatan lokasi hunian ini mempunyai kecenderungan adanya "pewarisan budaya" yang sama, yang menyebabkan terjadinya proses kehidupan yang terus berlanjut hingga sekarang. Kelanjutan budaya ini memang tidak akan 100 persen sama, pasti ada beberapa bagian yang mengalami perubahan atau pergeseran. Ada bagian budaya yang terus dilanjutkan dan ada juga yang tidak dilanjutkan pada generasi berikutnya, sehingga terjadi kemandekan budaya yang cukup signifikan. Tampaknya budaya rock-art yang pernah berkembang di sini tidak mempunyai generasi penerus yang memadai, sehingga hanya tinggal kisah dan sejarahnya saja. Kemampuan menggambar ini ada juga yang tetap dilakukan oleh masyarakat Dayak Lebo, seperti terlihat dalam pelaksanaan upacara adat di Desa Merabu Mapulu. 


\section{Referensi}

Chazine, Jean-Michel. 2002. Rock art and ceramics in East Borneo: logical discovery or new cornerstone? Pacific archaeology: assessment and prospect. Nourna: Les Cahiers d'Archaeologie 15. 2005. Rock art, burials, and habitations: cave in East Kalimantan. Asian Perspectives 44 (1): 219-230. . 2006. Sexual determination of hand stencils of the main panel of the Gua Masri II (East Kalimantan/Borneo-Indonesia. INNORA 44.

Chazine, Jean-Michel (et. al.). 2003. Report mission archaeology Kalimantan. . 2004. Report mission archaeology Kalimantan. . 2005. Report mission archaeology Kalimantan. . 2006. Report mission archaeology Kalimantan. . 2007. Report mission archaeology Kalimantan.
2008. Report mission archaeology Kalimantan. 2009. Report mission archaeology Kalimantan. . 2010. Report mission archaeology Kalimantan.

Jatmiko, Nasrudin, dan Bambang Sugiyanto. 2004. Eksplorasi situs gua dan ceruk hunian prasejarah di Pegunungan Marang, Kutai Timur, Kalimantan Timur. Laporan Penelitian Arkeologi. Jakarta: kerjasama Penelitian Asisten Deputi Urusan Arkeologi Nasional dan CREDO-CNRS, Maison Asie-Pasifique, Marseille-France. Belum diterbitkan.

Nasrudin. 2004. Temuan tanda tangan dan potensi situs gua-gua hunian di kawasan Pegunungan Marang, Kalimantan Timur. Kalpataru 17.

Sugiyanto, Bambang. 2010. Mengunjungi "museum" seni purba di Kalimantan. Naditira Widya 4(1): 129-138. 